\title{
Pengendalian Optimal Model Epidemi Flu Burung pada Unggas-Manusia dengan Pengobatan pada Manusia dan Depopulasi pada Unggas
}

\author{
Wahyuni Ningsih \\ Politeknik Negeri Malang \\ wahyuni_04@polinema.ac.id
}

\begin{abstract}
ABSTRAK
Pengendalian optimal terhadap penyebaran flu burung melalui pendekatan model epidemi flu burung pada unggas dan manusia dilakukan dengan menggunakan prinsip Pontryagin. Pengendalian ini bekerja dengan menambahkan variabel kendali pada model matematika dan mengoptimalkan fungsional objektif. Variabel kendali yang ditambahkan pada model berupa pengobatan pada subpopulasi manusia yang terinfeksi dan depopulasi pada subpopulasi unggas yang terinfeksi. Tujuan dari pengendalian ini yaitu untuk meminimumkan jumlah subpopulasi manusia yang terinfeksi dan jumlah subpopulasi unggas yang terinfeksi serta biaya yang diperlukan selama pengobatan dan depopulasi. Model diselesaikan secara numerik menggunakan metode Runge-Kutta. Sementara proses pengendalian diselesaikan secara numerik dengan bantuan toolbox DOTcvpSB pada bahasa pemrograman Matlab. Setelah dibandingkan dengan hasil simulasi numerik model epidemi flu burung tanpa kendali, hasil simulasi numerik model epidemi flu burung dengan kendali menunjukkan bahwa pengobatan mampu menurunkan jumlah subpopulasi manusia yang terinfeksi hampir $100 \%$. Begitu juga dengan depopulasi yang mampu menurunkan jumlah subpopulasi unggas yang terinfeksi hampir 100\%. Sehingga dengan kata lain penyebaran virus flu burung dapat dikendalikan dengan baik jika dilakukan depopulasi pada unggas yang terinfeksi dan pengobatan pada manusia yang terinfeksi.

Kata kunci: depopulasi, flu burung, kendali optimal, model epidemi, pengobatan, Pontryagin.
\end{abstract}

\section{ABSTRACT}

Optimal control of the spread of avian influenza in avian-human population through the epidemic model is carried out using Pontryagin principle. This control works by adding control variables to the mathematical model and optimizing the objective function. Treatment in the infected human subpopulation and depopulation in the infected avian subpopulation are added in the model as control variables. The aim of this control is to minimize the number of infected human subpopulations and the number of infected avian subpopulations as well as the costs involved during treatment and depopulation. The models are solved numerically using the Runge Kutta method. And the solution of optimal control is carried out using DOTcvpSB toolbox in Matlab. After comparing with the numerical simulation results of AI epidemic model without control, the results of a controlled AI epidemic model showed that treatment was able to reduce the number of infected people by almost 100\%. Likewise, depopulation was able to reduce the number of infected avian subpopulations by almost $100 \%$. So in other words, the spread of the avian influenza virus can be controlled properly if depopulation of infected avian and treatment of infected humans is carried out.

Keywords: avian influenza, depopulation, epidemic model, optimal control, Pontryagin, treatment. 



\section{PENDAHULUAN}

Virus avian influenza (AI) atau flu burung, khususnya yang tipe A (H5N1) sebagai salah satu penyakit zoonosis yang bersifat pandemik yang tidak hanya menyerang hewan (unggas) tapi juga menginfeksi manusia, telah mewabah di Afrika, Asia, Timur Tengah, dan beberapa wilayah di Eropa (WHO, 2021). Bermula dari tahun 1996, virus ini hanya menyerang unggas. Namun sejak tahun 1997, virus ini telah menginfeksi manusia di Hongkong (WHO, 2014). Kemudian sejak tahun 2003 hingga Januari 2021 telah dilaporkan sekitar 53\% manusia yang meninggal dari kasus yang terinfeksi virus H5N1 di dunia. Sementara itu, di Indonesia sendiri telah terkonfirmasi sebanyak 200 kasus dan 84\% nya meninggal terhitung sejak tahun 2005 hingga Januari 2021 (Biro Komunikasi dan Pelayanan Masyarakat, 2017).

Penularan virus flu burung lebih mudah terjadi di antara unggas dan dari unggas ke manusia, daripada penularan dari manusia ke manusia. Penularan virus ini biasanya terjadi baik pada unggas liar maupun unggas peternakan. Sementara manusia bisa tertular jika terjadi kontak langsung dengan unggas yang terinfeksi. Peristiwa ini kemudian digambarkan dalam model epidemi untuk diteliti dan dianalisis pola penyebarannya. Chong, dkk (Chong et al., 2014) mengembangkan model matematika penularan virus flu burung yang dipengaruhi halfsaturated incidence yang dapat menentukan tingkat terjangkitnya flu burung pada unggas dan manusia. Kemudian (Liu et al., 2016) mengkonstruksi model penularan dari unggas ke manusia dengan hukum yang berbeda dari populasi unggas, satu dengan pertumbuhan logistik dan yang lainnya dengan efek Allee. Serta analisis kestabilan yang dilakukan oleh (Ningsih, 2013) pada model epidemi flu burung pada unggas dan manusia dengan penambahan subpopulasi manusia dibawah pengaruh vaksinasi. Dan masih banyak yang lain dengan pendekatan atau sudut pandang masing-masing.

Penyebaran virus flu burung ini jelas memberikan dampak buruk. Tidak hanya dari sisi kesehatan pada manusia, tapi juga dari sisi ekonomi pada peternakan unggas. Upaya yang bisa dilakukan diantaranya yaitu dengan menjaga kesehatan diri, melakukan vaksinasi, isolasi mandiri ketika terinfeksi, dan tidak mendatangi area yang terjangkit wabah. Selain itu, depopulasi terhadap populasi unggas yang terinfeksi virus flu burung juga perlu dilakukan agar dapat meminimalisir bahkan menekan penyebaran virus. Melalui pendekatan model matematika, proses pengendalian suatu sistem bisa dilakukan dengan menerapkan prinsip Pontryagin seperti yang dilakukan oleh (Ningsih et al., 2019), (Kasbawati, 2011), (Taslima, 2011), (Agusto, 2013), dan (Izzati et al., 2020). Sementara analisis terhadap model matematika penyebaran virus flu burung pada unggas-manusia tanpa kendali telah dilakukan oleh beberapa peneliti seperti yang dilakukan oleh (Ningsih, 2013). Sehingga pada penelitian ini dilakukan pengendalian terhadap model matematika yang dikaji oleh (Ningsih, 2013) tersebut dengan menerapkan prinsip Pontryagin serta membandingkan hasil simulasi numerik dari model tanpa kendali tersebut dengan model di bawah pengaruh kendali.

\section{METODE}

Pengendalian terhadap model epidemi flu burung yang terjadi pada unggas dan manusia dilakukan dengan menggunakan prinsip Pontryagin. Prinsip Pontryagin secara umum bekerja 
dengan tujuan untuk mendapatkan nilai yang optimum dari variabel kendali (Naidu, 2002), (Sethi \& Thompson, 2000). Setelah diperoleh variabel kendali yang optimum, selanjutnya model diselesaikan secara numerik dan disimulasikan dengan memanfaatkan toolbox DOTcvpSB (Hirmajer et al., 2008) (Hirmajer et al., 2009). Dari hasil simulasi numerik diperoleh grafik profil variabel kendali dan profil perilaku sistem. Setelah itu dilakukan interpretasi untuk menggambarkan kondisi sistem dengan kendali. Serta membandingkan antara profil perilaku sistem tanpa kendali dengan sistem yang berada dibawah pengaruh kendali.

Model yang digunakan dalam penelitian ini yaitu model yang dikaji dan dianalisis kestabilannya oleh Ningsih (Ningsih, 2013). Model epidemi tersebut terdiri dari empat subpopulasi manusia dan dua subpopulasi unggas. Subpopulasi tersebut adalah $S_{b}(t)$ yaitu subpopulasi unggas yang rentan terhadap flu burung; $I_{b}(t)$ yaitu subpopulasi unggas yang terinfeksi flu burung; $S_{h}(t)$ yaitu subpopulasi manusia yang rentan terhadap flu burung; $V_{h}(t)$ yaitu subpopulasi manusia yang telah divaksin; $I_{h}(t)$ yaitu subpopulasi manusia yang terinfeksi flu burung; dan $R_{h}(t)$ yaitu subpopulasi manusia yang sembuh dari flu burung. Laju pertumbuhan tiap subpopulasi tersebut dipengaruhi oleh waktu $t$. Proses penularan flu burung tersebut digambarkan dalam diagram kompartemen yang ditunjukkan oleh Gambar 1 .

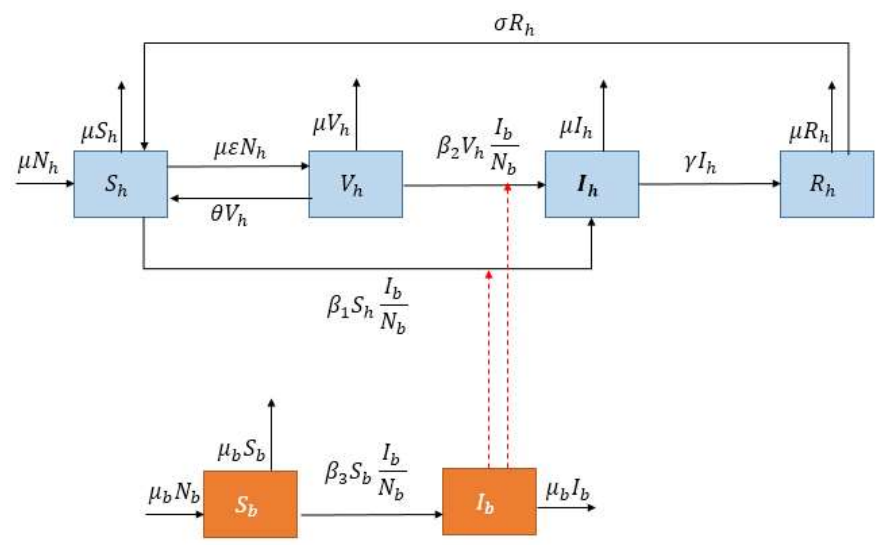

Gambar 1. Diagram Kompartemen Penularan Flu Burung pada Unggas-Manusia (Ningsih, 2013)

Berdasarkan diagram kompartemen dan asumsi yang dibangun, dapat dituliskan model matematikanya seperti yang ditunjukkan oleh Model (1).

$$
\begin{aligned}
& \dot{S}_{h}(t)=\mu(1-\varepsilon) N_{h}-\mu S_{h}(t)-\beta_{1} S_{h}(t) \frac{I_{b}(t)}{N_{b}}+\theta V_{h}(t)+\sigma R_{h}(t) \\
& \dot{V}_{h}(t)=\mu \varepsilon N_{h}-\beta_{2} V_{h}(t) \frac{I_{b}(t)}{N_{b}}-(\mu+\theta) V_{h}(t) \\
& \dot{I}_{h}(t)=\beta_{1} S_{h}(t) \frac{I_{b}(t)}{N_{b}}+\beta_{2} V_{h}(t) \frac{I_{b}(t)}{N_{b}}-(\gamma+\mu) I_{h}(t) \\
& \dot{R}_{h}(t)=\gamma_{h}(t)-(\mu+\sigma) R_{h}(t) \\
& \dot{S}_{b}(t)=\mu_{b} N_{b}-\mu_{b} S_{b}(t)-\beta_{3} S_{b}(t) \frac{I_{b}(t)}{N_{b}} \\
& \dot{I}_{b}(t)=\beta_{3} S_{b}(t) \frac{I_{b}(t)}{N_{b}}-\mu_{b} I_{b}(t)
\end{aligned}
$$


Dengan $N_{h}=S_{h}+V_{h}+I_{h}+R_{h}$ dan $N_{b}=S_{b}+I_{b}$ masing-masing adalah total dari tiap populasi. Adapun tiap asumsi parameternya yaitu tingkat kelahiran dan kematian manusia $\mu$ yang nilainya dianggap sama, tingkat kelahiran dan kematian unggas $\mu_{b}$ yang nilainya dianggap sama, tingkat kontak rata-rata antara manusia rentan dan unggas terinfeksi $\beta_{1}$, tingkat kontak rata-rata antara manusia yang divaksin dengan unggas terinfeksi $\beta_{2}$, tingkat kontak rata-rata antara unggas rentan dengan unggas terinfeksi $\beta_{3}$, bagian dari populasi manusia yang diberi vaksin (obat pencegah flu) $\varepsilon$, tingkat kesembuhan manusia yang terinfeksi $\gamma$, tingkat hilangnya kekebalan manusia sehat sehingga kembali rentan $\sigma$, dan tingkat menurunnya vaksin pada manusia akibat hilangnya kekebalan alami sehingga kembali rentan $\theta$. Semua nilai parameter tersebut diasumsikan bernilai positif. Hasil analisis stabilitas model yang dikaji oleh (Ningsih, 2013) tersebut menunjukkan bahwa penyebaran virus flu burung pada unggas-manusia masih terjadi karena titik setimbang endemiknya bersifat stabil asimtotis lokal.

\section{HASIL DAN PEMBAHASAN}

\subsection{Model Epidemi Flu Burung dengan Kendali}

Pengembangan Model (1) dilakukan dengan menambah varibel kendali $u_{1}(t)$ sebagai depopulasi pada subpopulasi unggas yang terinfeksi dan $u_{2}(t)$ sebagai pengobatan pada subpopulasi manusia yang terinfeksi (mengganti parameter $\gamma$ ). Untuk lebih jelasnya, kondisi ini dapat diilustrasikan dalam diagram kompartemen yang ditunjukkan oleh Gambar 2.

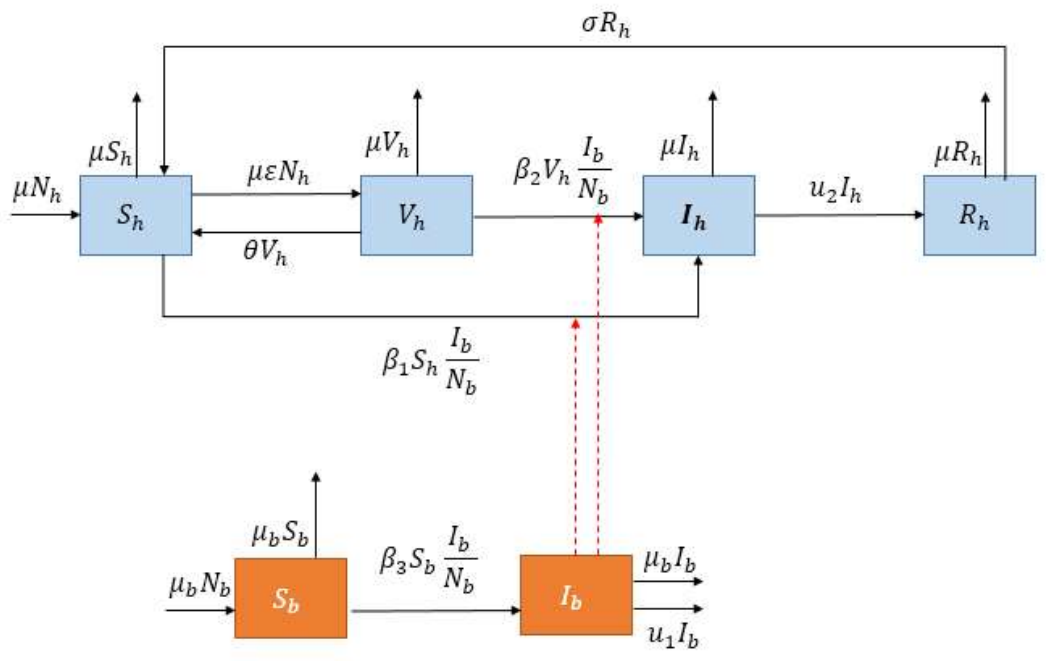

Gambar 2. Model Epidemi Flu Burung dengan Kendali

Berdasarkan diagram kompartemen Gambar 2, pengembangan Model (1) dituliskan dalam Model (2). Adapun tujuan dari penambahan variabel kendali $u_{1}(t)$ dan $u_{2}(t)$ yaitu untuk menekan laju pertumbuhan subpopulasi yang terinfeksi. Dengan adanya $u_{1}(t)$ diharapkan laju pertumbuhan subpopulasi unggas yang terinfeksi $I_{b}$ menurun sehingga tingkat individu yang terinfeksi dapat berkurang. Begitu juga dengan $u_{2}(t)$ diharapkan laju pertumbuhan subpopulasi $I_{h}$ dapat menurun atau dengan kata lain sembuh melalui pengobatan yang diberikan. 


$$
\begin{aligned}
& \dot{S}_{h}(t)=\mu(1-\varepsilon) N_{h}-\mu S_{h}(t)-\beta_{1} S_{h}(t) \frac{I_{b}(t)}{N_{b}}+\theta V_{h}(t)+\sigma R_{h}(t) \\
& \dot{V}_{h}(t)=\mu \varepsilon N_{h}-\beta_{2} V_{h}(t) \frac{I_{b}(t)}{N_{b}}-(\mu+\theta) V_{h}(t) \\
& \dot{I}_{h}(t)=\beta_{1} S_{h}(t) \frac{I_{b}(t)}{N_{b}}+\beta_{2} V_{h}(t) \frac{I_{b}(t)}{N_{b}}-\left(u_{2}(t)+\mu\right) I_{h}(t) \\
& \dot{R}_{h}(t)=u_{2}(t) I_{h}(t)-(\mu+\sigma) R_{h}(t) \\
& \dot{S}_{b}(t)=\mu_{b} N_{b}-\mu_{b} S_{b}(t)-\beta_{3} S_{b}(t) \frac{I_{b}(t)}{N_{b}} \\
& \dot{I}_{b}(t)=\beta_{3} S_{b}(t) \frac{I_{b}(t)}{N_{b}}-\mu_{b} I_{b}(t)-u_{1}(t) I_{b}(t)
\end{aligned}
$$

\subsection{Daerah Batas Penyelesaian}

Batasan penyelesaian Model (2) dapat diperoleh dengan cara mengasumsikan bahwa $N_{h}(t)=S_{h}(t)+V_{h}(t)+I_{h}(t)+R_{h}(t) \quad$ sehingga $\quad \frac{d N_{h}(t)}{d t}=\frac{d S_{h}(t)}{d t}+\frac{d V_{h}(t)}{d t}+\frac{d I_{h}(t)}{d t}+\frac{d R_{h}(t)}{d t}$. Dengan mensubstitusi Model (2), maka diperoleh $N_{h}(t)=C$ dengan $C$ bernilai konstan. Dan diasumsikan tiap subpopulasi bernilai positif. Sehingga dapat dikatakan $0<N_{h}(t) \leq C$.

\subsection{Kendali Optimal pada Model}

Setelah terbentuk model matematika dengan variabel kendali yaitu Model (2), maka selanjutnya menentukan performa index yang digunakan. Pengendalian ini bertujuan untuk meminimumkan fungsi biaya atau performa index atau fungsional objektif yang ditunjukkan oleh persamaan (3).

$$
J\left(u_{1}, u_{2}\right)=\int_{0}^{T}\left[I_{b}(t)+I_{h}(t)+\frac{A_{1}}{2} u_{1}^{2}+\frac{A_{2}}{2} u_{2}^{2}\right] d t
$$

Adapun yang akan diminimumkan yaitu jumlah subpopulasi unggas yang terinfeksi dan jumlah subpopulasi manusia yang terinfeksi. Selain itu biaya atas pengobatan $I_{h}(t)$ dan depopulasi $I_{b}(t)$ juga diminimumkan. Sehingga fungsi biaya tersebut nonlinear. Fungsional objektif berbentuk quadratik dimaksudkan untuk menghitung biaya pengendalian. Sementara $A_{1}$ dan $A_{2}$ bertindak sebagai koefisien penyeimbang. Penentuan variabel kendali yang optimal $u_{1}^{*}$ dan $u_{2}^{*}$ dapat dituliskan sebagai

$$
J\left(u_{1}^{*}, u_{2}^{*}\right)=\min _{u}\left\{J\left(u_{1}, u_{2}\right)\right\}
$$

dengan himpunan kendali $U=\left\{\left(u_{1}(t), u_{2}(t)\right) \mid 0 \leq u_{i}(t) \leq 1, i=1,2\right\}$.

Langkah selanjutnya yaitu menentukan solusi kendali optimal yang diperoleh dengan cara menentukan bentuk Lagrangian dari persamaan (3) terlebih dahulu yaitu

$$
L=I_{b}(t)+I_{h}(t)+\frac{A_{1}}{2} u_{1}^{2}+\frac{A_{2}}{2} u_{2}^{2} .
$$

Sehingga bentuk fungsi Hamiltoniannya yaitu

$$
H=L+\vec{\lambda}^{T} \vec{f}
$$


dengan

$$
\vec{\lambda}^{T}=\left[\begin{array}{llllll}
\lambda_{S_{h}} & \lambda_{V_{h}} & \lambda_{I_{h}} & \lambda_{R_{h}} & \lambda_{S_{b}} & \lambda_{I_{b}}
\end{array}\right]
$$

dan

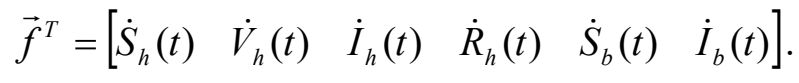

Selanjutnya menentukan kondisi stasioner dari Hamiltonian dengan meminimumkan fungsi $H$ terhadap $u_{1}, u_{2}$.

$$
\begin{aligned}
& \left(\frac{\partial H}{\partial u_{1}}\right)_{*}=0 \Leftrightarrow u_{1}=\frac{\lambda_{I_{b}}^{*} I_{b}^{*}}{A_{1}} \\
& \left(\frac{\partial H}{\partial u_{2}}\right)_{*}=0 \Leftrightarrow u_{2}=\frac{\lambda_{I_{h}}^{*} I_{h}^{*}-\lambda_{R_{h}}^{*} I_{h}^{*}}{A_{2}}
\end{aligned}
$$

Sehingga diperoleh variabel kendali yang optimal yaitu

$$
u_{1}^{*}=\min \left\{1, \max \left[0, \frac{\lambda_{I_{b}}^{*} I_{b}^{*}}{A_{1}}\right]\right\} \text { dan } u_{2}^{*}=\min \left\{1, \max \left[0, \frac{\lambda_{I_{h}}^{*} I_{h}^{*}-\lambda_{R_{h}}^{*} I_{h}^{*}}{A_{2}}\right]\right\}
$$

Formula variabel kendali yang optimal tersebut kemudian disubstitusikan ke persamaan Hamiltonian untuk memperoleh formula Hamiltonian $H^{*}$ yang optimal. Dari $H^{*}$ selanjutnya ditentukan variabel state dan costate yang optimal sebagai berikut.

\section{Variabel State}

$$
\begin{aligned}
& \left(\dot{S}_{h}(t)\right)^{*}=\left(\frac{\partial H}{\partial \lambda_{S_{h}}}\right) * \mu(1-\varepsilon) N_{h}-\mu S_{h}^{*}(t)-\beta_{1} S_{h}^{*}(t) \frac{I_{b}^{*}(t)}{N_{b}}+\theta V_{h}^{*}(t)+\sigma R_{h}^{*}(t) \\
& \left(\dot{V}_{h}(t)\right)^{*}=\left(\frac{\partial H}{\partial \lambda_{V_{h}}}\right)_{*}=\mu \varepsilon N_{h}-\beta_{2} V_{h}^{*}(t) \frac{I_{b}^{*}(t)}{N_{b}}-(\mu+\theta) V_{h}^{*}(t) \\
& \left(\dot{I}_{h}(t)\right)^{*}=\left(\frac{\partial H}{\partial \lambda_{I_{h}}}\right)_{*}=\beta_{1} S_{h}^{*}(t) \frac{I_{b}^{*}(t)}{N_{b}}+\beta_{2} V_{h}^{*}(t) \frac{I_{b}^{*}(t)}{N_{b}}-\frac{2 \lambda_{I_{h}}^{*} I_{h}^{* 2}(t)}{A_{2}}+\frac{2 \lambda_{R_{h}}^{*} I_{h}^{* 2}(t)}{A_{2}}-\mu I_{h}^{*}(t) \\
& \left(\dot{R}_{h}(t)\right)^{*}=\left(\frac{\partial H}{\partial \lambda_{R_{h}}}\right) *=\frac{\lambda_{I_{h}}^{*} I_{h}^{* 2}(t)}{A_{2}}-\frac{2 \lambda_{R_{h}}^{*} I_{h}^{* 2}(t)}{A_{2}}-(\mu+\sigma) R_{h}^{*}(t) \\
& \left(\dot{S}_{b}(t)\right)^{*}=\left(\frac{\partial H}{\partial \lambda_{S_{b}}}\right) *=\mu_{b} N_{b}-\mu_{b} S_{b}^{*}(t)-\beta_{3} S_{b}^{*}(t) \frac{I_{b}^{*}(t)}{N_{b}} \\
& \left(\dot{I}_{b}(t)\right)^{*}=\left(\frac{\partial H}{\partial \lambda_{I_{b}}}\right)_{*}=\beta_{3} S_{b}^{*}(t) \frac{I_{b}^{*}(t)}{N_{b}}-\mu_{b} I_{b}^{*}(t)-\frac{2 \lambda_{I_{b}}^{*} I_{b}^{* 2}(t)}{A_{1}}
\end{aligned}
$$

Variabel Costate

$$
\begin{aligned}
& \left(\dot{\lambda}_{S_{h}}(t)\right)^{*}=-\left(\frac{\partial H}{\partial S_{h}}\right) * \lambda_{S_{h}}^{*}\left(\mu+\beta_{1} \frac{I_{b}^{*}(t)}{N_{b}}\right)-\lambda_{I_{h}}^{*}\left(\beta_{1} \frac{I_{b}^{*}(t)}{N_{b}}\right) \\
& \left(\dot{\lambda}_{V_{h}}(t)\right)^{*}=-\left(\frac{\partial H}{\partial V_{h}}\right) *=-\lambda_{S_{h}}^{*} \theta+\lambda_{V_{h}}^{*}\left(\beta_{2} \frac{I_{b}^{*}(t)}{N_{b}}+(\mu+\theta)\right)-\lambda_{I_{h}}^{*} \beta_{2} \frac{I_{b}^{*}(t)}{N_{b}}
\end{aligned}
$$




$$
\begin{aligned}
& \left(\dot{\lambda}_{I_{h}}(t)\right)^{*}=-\left(\frac{\partial H}{\partial I_{h}}\right) *=\lambda_{I_{h}}^{*}\left(\frac{2\left(\lambda_{I_{h}}^{*}-\lambda_{R_{h}}^{*}\right) I_{h}^{*}(t)}{A_{2}}+\mu\right)-\lambda_{R_{h}}^{*} \frac{2\left(\lambda_{I_{h}}^{*}-\lambda_{R_{h}}^{*}\right) I_{h}^{*}(t)}{A_{2}} \\
& \left(\dot{\lambda}_{R_{h}}(t)\right)^{*}=-\left(\frac{\partial H}{\partial R_{h}}\right)_{*}=-\lambda_{S_{h}}^{*} \sigma+\lambda_{R_{h}}^{*}(\mu+\sigma) \\
& \left(\dot{\lambda}_{S_{b}}(t)\right)^{*}=-\left(\frac{\partial H}{\partial S_{b}}\right)_{*}=\lambda_{S_{b}}^{*}\left(\mu_{b}+\beta_{3} \frac{I_{b}^{*}(t)}{N_{b}}\right)-\lambda_{I_{b}}^{*} \beta_{3} \frac{I_{b}^{*}(t)}{N_{b}} \\
& \left(\dot{\lambda}_{I_{b}}(t)\right)^{*}=-\left(\frac{\partial H}{\partial I_{b}}\right)=-\left(-\lambda_{S_{b}}^{*} \beta_{3} \frac{S_{b}^{*}(t)}{N_{b}}+\lambda_{I_{b}}^{*}\left(\beta_{3} \frac{S_{b}^{*}(t)}{N_{b}}-\mu_{b}-\frac{2 \lambda_{I_{b}}^{*} I_{b}^{*}(t)}{A_{1}}\right)\right)
\end{aligned}
$$

Terlihat bahwa variabel state dan costatenya berbentuk nonlinear. Sehingga solusinya tidak dapat diperoleh secara analitik. Untuk itu, diperlukan bantuan toolbox DOTcvpSB pada bahasa pemrograman Matlab untuk memperoleh solusi numeriknya yang diilustrasikan dalam bentuk grafik.

\subsection{Simulasi Numerik dan Analisis Hasil}

Solusi numerik pada Model (1) dan Model (2) dilakukan dengan menerapkan metode Runge-Kutta orde 4. Kemudian hasilnya disimulasikan menggunakan bahasa pemrograman Matlab. Adapun nilai parameter dari model yang digunakan dalam simulasi numerik ditunjukkan oleh Tabel 1. Dan nilai awal tiap variabel diasumsikan $S_{h}(0)=V_{h}(0)=I_{h}(0)=$ $R_{h}(0)=S_{b}(0)=I_{b}(0)=1$.

Dengan menggunakan nilai parameter pada Tabel 1, maka hasil simulasi dari model epidemi flu burung pada unggas-manusia tanpa kendali ditunjukkan oleh Gambar 3. Sementara hasil simulasi dari model epidemi flu burung pada unggas-manusia dengan kendali ditunjukkan oleh Gambar 4.

\begin{tabular}{cc}
\multicolumn{2}{c}{ Tabel 1. Asumsi Nilai Parameter } \\
\hline Parameter & Nilai \\
\hline$\mu$ & 0,2 \\
$\mu_{b}$ & 0,02 \\
$\beta_{1}$ & 0,026 \\
$\beta_{2}$ & 0,035 \\
$\beta_{3}$ & 0,045 \\
$\varepsilon$ & 0,2 \\
$\theta$ & 0,06 \\
$\sigma$ & 0,04 \\
$\gamma$ & 0,09 \\
$A_{1}$ & 0,01 \\
$A_{2}$ & 0,01 \\
\hline
\end{tabular}




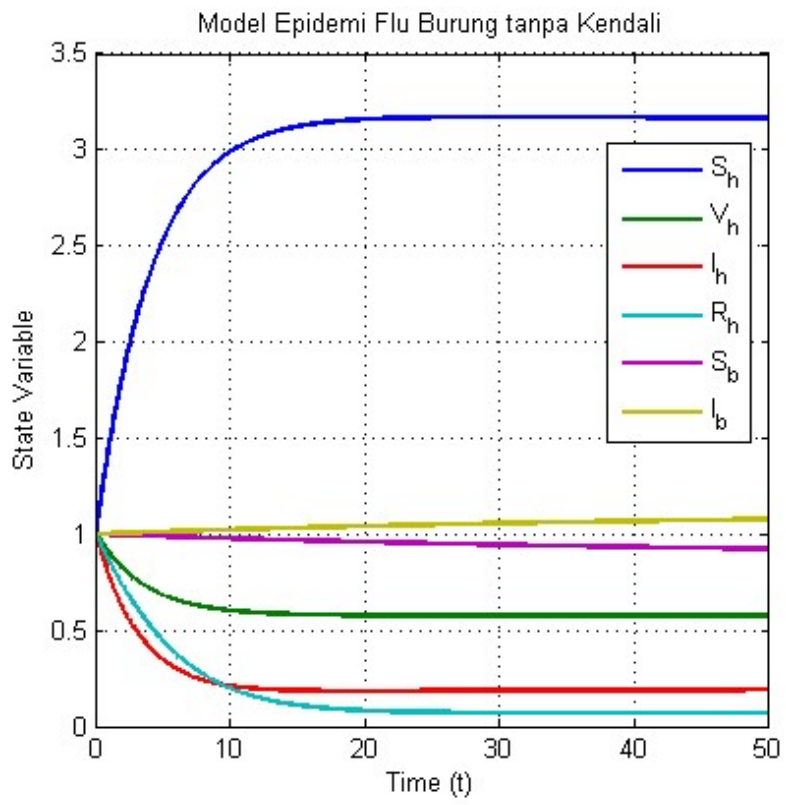

Gambar 3. Profil Penyebaran Virus Flu Burung pada Unggas-Manusia Tanpa Kendali

Dari Gambar 3 tersebut, terlihat bahwa subpopulasi manusia yang terinfeksi $I_{h}$ masih ada meskipun cenderung stabil. Begitu juga dengan subpopulasi unggas yang terinfeksi $I_{b}$ juga masih ada bahkan menunjukkan peningkatan jumlah subpopulasi. Kondisi ini bisa dilihat pada Tabel 2.

Tabel 2. Perkembangan Nilai Variabel State $I_{h}$ dan $I_{b}$

\begin{tabular}{cccccc}
\hline \multirow{2}{*}{ Variabel State } & \multicolumn{5}{c}{ Nilai Variabel State Tiap Waktu } \\
\cline { 2 - 6 } & $\mathbf{1 0}$ & $\mathbf{2 0}$ & $\mathbf{3 0}$ & $\mathbf{4 0}$ & $\mathbf{5 0}$ \\
\hline$I_{h}$ & 0.2097 & 0.1834 & 0.1857 & 0.1879 & 0.1896 \\
$I_{b}$ & 1.0226 & 1.0410 & 1.0557 & 1.0675 & 1.0768 \\
\hline
\end{tabular}

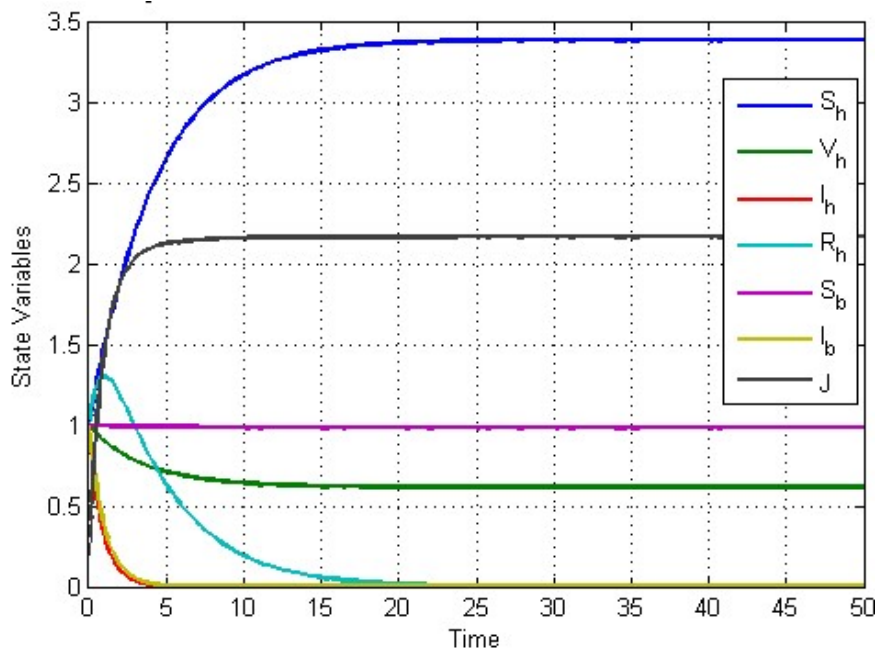

Gambar 4. Profil Penyebaran Virus Flu Burung pada Unggas-Manusia dengan Kendali 
Hasil simulasi dari Model (2) yang ditunjukkan oleh Gambar 4 berupa semakin menurunnya tingkat penyebaran flu burung pada unggas-manusia. Terlihat bahwa subpopulasi manusia yang terinfeksi $I_{h}$ dan subpopulasi unggas yang terinfeksi $I_{b}$ nilai variabel statenya mendekati nol dalam rentang waktu $0<t<5$.

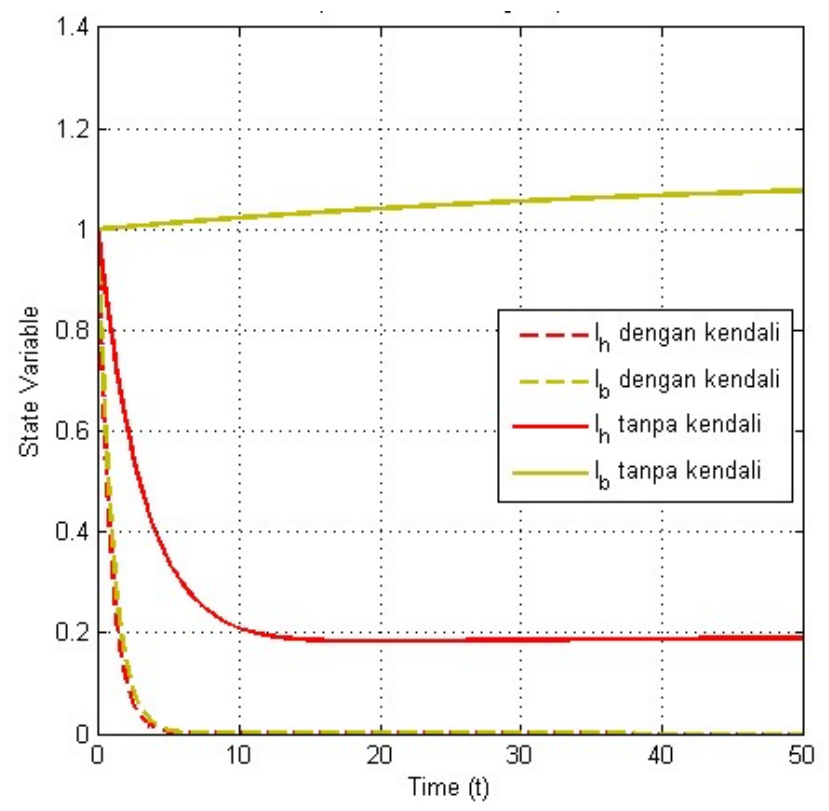

Gambar 5. Profil Subpopulasi Manusia yang Terinfeksi dan Subpopulasi Unggas yang Terinfeksi Sebelum Dilakukan Pengendalian dan Setelah Dilakukan Pengendalian.

Kondisi dari Gambar 3 dan Gambar 4 lebih jelasnya ditunjukkan oleh Gambar 5 yaitu grafik perbandingan antara profil subpopulasi manusia yang terinfeksi $I_{h}$ dan profil subpopulasi unggas yang terinfeksi $I_{b}$ sebelum dan sesudah pengendalian. Pada Gambar 5 tersebut terlihat bahwa sebelum dilakukan pengendalian, jumlah subpopulasi $I_{h}$ dan $I_{b}$ tidak menunjukkan penurunan. Dengan kata lain masih terjadi penyebaran virus baik pada populasi unggas maupun manusia. Sementara setelah dilakukan upaya pengendalian, pada Gambar 5 tersebut terlihat bahwa jumlah subpopulasi $I_{h}$ dan $I_{b}$ mengalami penurunan yang signifikan. Hal ini juga diperkuat oleh nilai dari kedua variabel state tersebut untuk tiap waktu tertentu yang ditunjukkan oleh Tabel 3 berikut.

Tabel 3. Perbandingan Nilai Variabel State $I_{h}$ dan $I_{b}$ Sebelum dan Sesudah Pengendalian

\begin{tabular}{ccccccc}
\hline Kondisi* & \multicolumn{6}{c}{ Nilai Variabel State tiap Waktu } \\
\cline { 2 - 7 } & \multicolumn{6}{c}{$\boldsymbol{I}_{\boldsymbol{h}}$} \\
\cline { 2 - 7 } & $\mathbf{1 0}$ & $\mathbf{3 0}$ & $\mathbf{5 0}$ & $\mathbf{1 0}$ & $\mathbf{3 0}$ & $\mathbf{5 0}$ \\
\hline $\mathrm{T}$ & 0.2097 & 0.1857 & 0.1896 & 1.0226 & 1.0557 & 1.0768 \\
$\mathrm{~K}$ & 0.00084 & 0.00004 & 0.00001 & 0.0011 & 0.00007 & 0.00002 \\
\hline \multicolumn{6}{c}{ *keterangan: T artinya tanpa kendali, K artinya dengan kendali }
\end{tabular}

Berdasarkan simulasi tersebut, pengobatan pada manusia dan depopulasi pada unggas yang secara berturut-turut dinyatakan sebagai variabel kendali $\boldsymbol{u}_{\mathbf{2}}(\boldsymbol{t})$ dan $\boldsymbol{u}_{\mathbf{1}}(\boldsymbol{t})$ dapat bekerja dengan baik. Profil dari variabel kendali ini ditunjukkan oleh Gambar 6. 


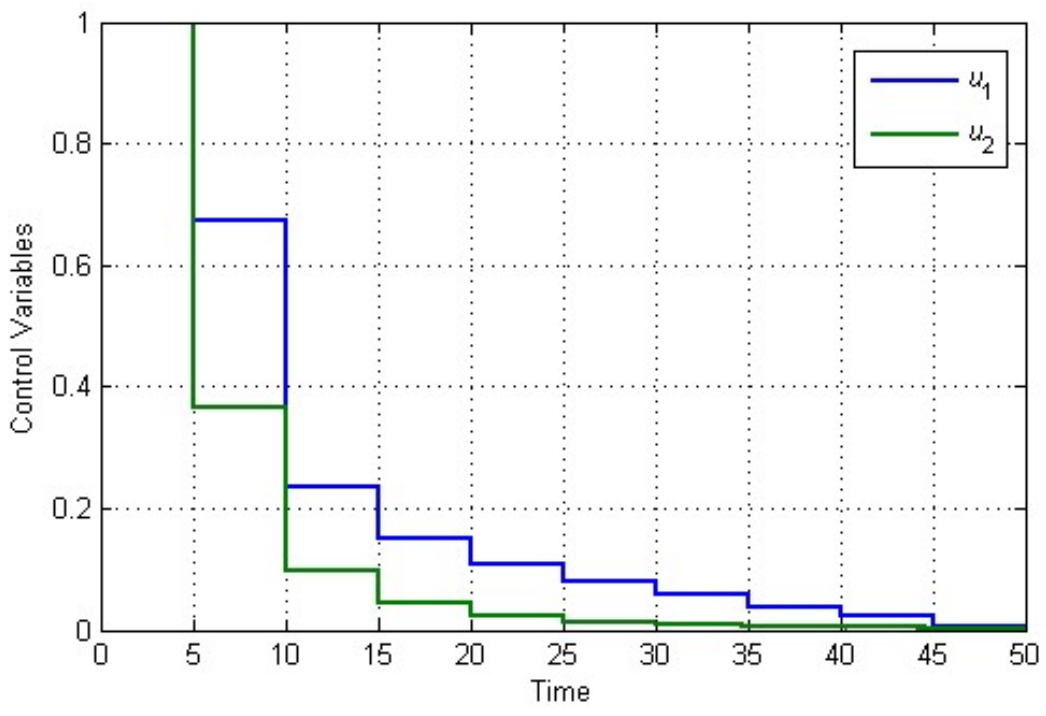

Gambar 6. Profil Variabel Kendali $u_{1}(t)$ dan $u_{2}(t)$

Dari Gambar 6 tersebut terlihat bahwa nilai variabel kendali diberikan secara maksimal yaitu $u_{1}=1$ dan $u_{2}=1$ untuk rentang waktu $0 \leq t<5$. Dengan kata lain, pada waktu rentang ini, pengendalian dilakukan secara maksimal untuk menekan jumlah subpopulasi $I_{h}$ dan $I_{b}$ (lihat Gambar 5.). Meskipun jumlah subpopulasi $I_{h}$ dan $I_{b}$ sudah dapat dikendalikan, namun pengendalian terus dilakukan dengan menurunkan tingkat pengendalian (nilai variabel kendali) secara bertahap tiap waktu hingga penyebaran virus flu burung dapat dikendalikan secara optimal.

\section{SIMPULAN}

Penyebaran virus flu burung pada unggas-manusia yang dimodelkan dalam matematika ini dapat terlihat bahwa proses pengendalian dapat dilakukan. Upaya pengobatan pada manusia yang terinfeksi dan depopulasi pada unggas yang terinfeksi yang telah ditambahkan sebagai variabel kendali mampu mengendalikan jumlah yang terinfeksi tersebut dengan baik. Hal ini ditunjukkan dengan menurunnya jumlah subpopulasi baik pada subpopulasi manusia yang terinfeksi $I_{h}$ maupun pada subpopulasi unggas yang terinfeksi $I_{b}$ ketika dalam pengendalian jika dibandingkan dengan jumlah keduanya ketika belum dilakukan pengendalian. Penurunan jumlah subpopulasi dari masing-masing subpopulasi ini berkisar 99,9\%. Sehingga dapat dikatakan bahwa pengendalian yang dilakukan secara bertahap sesuai dengan profil variabel kendali ini dapat dijadikan sebagai acuan dalam meminimumkan jumlah subpopulasi yang terinfeksi tersebut. Dengan demikian penyebaran virus flu burung dapat dikendalikan dengan optimal. Namun, model yang digunakan dalam penelitian ini masih sederhana. Sehingga kedepannya bisa dilakukan penelitian lebih lanjut dengan mengembangkan model menjadi lebih kompleks dan mendekati kondisi yang sebenarnya. 


\section{DAFTAR PUSTAKA}

Agusto, F. B. (2013). Optimal isolation control strategies and cost-effectiveness analysis of a two-strain avian influenza model. BioSystems Journal, 113, 155-164.

Biro Komunikasi dan Pelayanan Masyarakat. (2017). Kemenkes Umumkan Kasus Flu Burung ke 200. Kementerian Kesehatan RI.

Chong, N. S., Tchyenche, J. M., \& Smith, R. J. (2014). A mathematical model of avian influenza with half-saturated incidence. Theory Biosci, 133, 23-38.

Hirmajer, T., Balsa Canto, E., \& Banga, J. R. (2009). DOTcvpSB a Software Toolbox for Dynamic Optimization in System Biology. BMC Bioinformatics, 10(199), 1-14.

Hirmajer, T., Balsa Canto, E., Fikar, M., \& Banga, J. R. (2008). Technical Report DOTcvp: Dynamic Optimization Toolbox with Control Vector Parameterization approach. https://www.researchgate.net/publication/228552084

Izzati, N., Andriani, A., \& Robi'aqolbi, R. (2020). Optimal control of diphtheria epidemic model with prevention and treatment. Journal of Physics : Conference Series, 1663.

Kasbawati. (2011). Kontrol Optimal Upaya Pencegahan Infeksi Virus Flu Burung H5N1 dalam Populasi Burung dan Manusia. Jurnal Matematika, Statistika, \& Komputasi, 8(1), $12-24$.

Liu, S., Ruan, S., \& Zhang, X. (2016). Nonlinear Dynamics of Avian Influenza Epidemic Models. Mathematical Biosciences.

Naidu, D. S. (2002). Optimal Control Systems. CRC Press.

Ningsih, W. (2013). Analisis Stabilitas dan Sensitivitas Model Epidemik Flu Burung pada Unggas-Manusia dengan Vaksinasi [Program Sarjana]. Matematika ITS.

Ningsih, W., Sumardi, Riskiyah, I., \& Arystianto, D. (2019). Kendali Optimal Model Matematika Penyebaran Rumor pada Jaringan Sosial Daring dengan Pemberian Pernyataan Balasan. Prosiding SI MaNIs, 3, 017-027. http://conferences.uinmalang.ac.id/index.php/SIMANIS/article/view/903

Sethi, S. P., \& Thompson, G. L. (2000). Optimal Control Theory Application to Management Science and Economics Second Edition. Springer.

Taslima. (2011). Kendali Optimal pada Pencegahan Wabah Flu Burung dengan Eliminasi, Karantina, dan Pengobatan. Institut Teknologi Sepuluh Nopember Surabaya.

WHO. (2014). H5N1 highly pathogenic avian influenza: Timeline of major events. www.who.int

WHO. (2021). Cumulative number of confirmed human cases for avian influenza A(H5N1) reported to $\mathrm{WHO}, 2003-2020$. www.who.int 